\title{
REVIEW
}

\section{A review of home-based physical activity interventions for breast cancer survivors}

\author{
Steven S. Coughlin ${ }^{1,2^{*}} \quad$ Lee Caplan $^{3} \quad$ Rebecca Stone $^{2} \quad$ Jessica Stewart $^{4}$
}

\begin{abstract}
As breast cancer relative survival continues to increase, many breast cancer patients face many issues, including recurrence of cancer and cancer-related side effects that impact several aspects of their quality of life. With breast cancer patients living longer, there is more of a concern for negative breast cancer outcomes. Although physical activity is an affordable and relatively convenient way to improve breast cancer outcomes, only about one-third of breast cancer survivors engage in the recommended level of physical activity. This article reviews articles published to date to examine whether home-based physical activity interventions are effective in improving physical activity and other outcomes among breast cancer survivors who have completed primary therapy for the disease. The present review is based upon bibliographic searches in PubMed and CINAHL and relevant search terms. Articles published in English from 1980 through February 28, 2019 were identified. A total of 360 article citations were identified in PubMed and non-duplicates in CINAHL. After screening the abstracts or full texts of these articles and reviewing the references of previous review articles, 20 studies that met the eligibility criteria. Three of the studies were pre-/post-test trials and 17 were randomized controlled trials. Home-based exercise programs are effective in improving physical activity among breast cancer survivors who have completed primary therapy for the disease. Home-based exercise programs such as walking programs offer a convenient and affordable option for women who wish to increase their physical activity and maintain a healthy lifestyle.
\end{abstract}

Keywords: breast cancer survivors, physical activity, women

\section{Introduction}

The five-year relative breast cancer survival rate in the US continues to increase and is now about $91 \%^{[1]}$. As the rate increases, many breast cancer patients face many issues, including recurrence of cancer and cancerrelated side effects that impact several aspects of their quality of life ${ }^{[2]}$. To reduce risk of cancer recurrence, the American Institute for Cancer Research also recommends that cancer survivors meet physical activity guidelines $(\mathrm{AICR})^{[3]}$. Of women diagnosed with breast cancer, 50-96\% experience weight gain during treatment ${ }^{[4]}$. This weight gain after diagnosis usually ranges between

Received: June 14, 2019; Accepted: July 25, 2019; Published: July 30, 2019

*Correspondence to: Steven S. Coughlin, Department of Population Health Sciences, Medical College of Georgia, Augusta University, 1120 15th Street, Augusta, GA 30912, USA; Email: scoughlin@augusta.edu

${ }^{1}$ Department of Population Health Sciences, Medical College of Georgia, Augusta University, Augusta, GA 30912, USA

${ }^{2}$ Institute of Public \& Preventive Health, Augusta University, Augusta, GA 30912, USA

${ }^{3}$ Morehouse School of Medicine, Department of Community Health and Preventive Medicine, Atlanta, GA 30310, USA

${ }^{4}$ Department of Interdisciplinary Health Sciences, College of Allied Health Sciences, Augusta University, Augusta, GA 30310, USA

Citation: Coughlin SS, Caplan L, Stone R, et al. A review of home-based physical activity interventions for breast cancer survivors. Curr Cancer Rep, 2019, 1(1): 6-12.

Copyright: (c) 2019 Steven S. Coughlin, et al. This is an open access article distributed under the terms of the Creative Commons Attribution License, which permits unrestricted use, distribution, and reproduction in any medium, provided the original author and source
are credited.
2.5 and $6.2 \mathrm{~kg}$ (5.5 to $13.6 \mathrm{lbs})^{[5]}$. Among breast cancer survivors (BCSs), physical activity improves physical functioning, cardiovascular fitness, emotional wellbeing, and psychological adjustment, while lowering fatigue, depression, and anxiety, and helping to maintain a healthy body weight ${ }^{[6]}$. In addition, studies suggest that the immunological status of breast cancer patients improves after physical activity ${ }^{[7]}$. However, levels of physical activity in this population are low.

Physical inactivity and excessive weight gain that can occur following breast cancer treatment increases the risk of breast cancer recurrence, other chronic diseases, and all-cause and breast cancer-related mortal${ }_{i t y}{ }^{[8]}$. Physical inactivity increases the risk of obesity, which increases circulating estrogen levels and mortality. Exercise can lower circulating levels of estrogen and potentially reduce tumor proliferation. Although physical activity is an affordable and relatively convenient way to improve breast cancer outcomes, only about one-third of breast cancer survivors engage in the recommended level of physical activity ${ }^{[9]}$.

Home-based exercise programs, including walking programs, offer a convenient and affordable option for women who wish to increase their physical activity and maintain a healthy lifestyle. This manuscript reviews ar- 
ticles published to date to examine whether home-based physical activity interventions are effective in increasing physical activity and improving other outcomes among breast cancer survivors who have completed primary therapy for the disease (adjuvant chemotherapy, radiation, or surgery).

\section{Methods}

The present review is based upon bibliographic searches in PubMed and CINAHL (Cummulative Index to Nursing and Allied Health Literature) and relevant search terms. Articles published in English from 1980 through February 28, 2019 were identified using the following MeSH (Medical Subject Heading) search terms and Boolean algebra commands: home based AND physical activity AND breast cancer. The following MeSH search terms and Boolean algebra commands were also used: walking intervention AND breast cancer. The searches were not limited to words appearing in the title of an article nor to studies in a particular country or geographic region of the world. The references of review articles were also reviewed (Bluethman et al. 2015; Paxton et al. 2019). Information obtained from bibliographic searches (title and topic of article, information in abstract, study design, and key words) was used to determine whether or not to retain each identified article. Only studies written in English that examined the impact of breast cancer survivorship care plans on health outcomes were eligible for inclusion.

\section{Results}

A total of 360 article citations were identified in PubMed and non-duplicates in CINAHL (Figure 1). After screening the abstracts or full texts of these articles and reviewing the references of previous review articles, we were left with 20 studies that met the eligibility criteria. Three of the studies were pre-/post-test trials, and 17 were randomized controlled trials.

Pinto et al. ${ }^{[10]}$ conducted a 12 -week randomized controlled trial of physical activity counseling delivered via telephone, combined with weekly exercise tip sheets (Table 1). Eighty-six women who had completed therapy for stage 0-II breast cancer were enrolled in the trial. The physical activity group reported significantly more total minutes of physical activity and more minutes of moderate-intensity physical activity than the control group $(\mathrm{p}=0.001)$.

In an eight-week pre/post-test trial of a community intervention that combined the use of pedometers with scheduling, goal setting, and self-assessment, Wilson et $a l .{ }^{[11]}$ found that the intervention led to significant in-

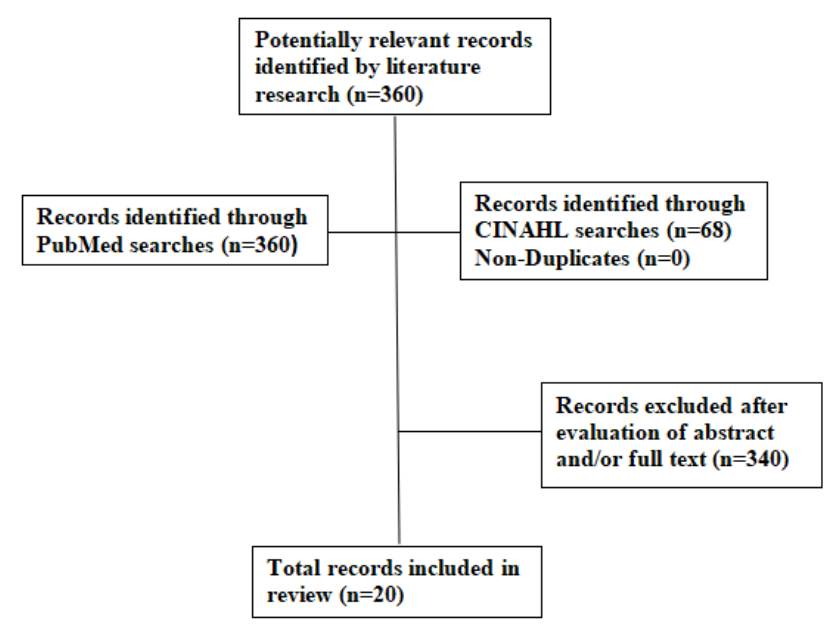

Figure 1. Flowchart of record selection process

creases in steps walked per day and improved attitude toward exercise, as well as significant decreases in body mass index and other anthropometric measures. Twentyfour African American breast cancer survivors were enrolled in the trial.

Vallance et al. ${ }^{[12]}$ conducted a 12-week randomized controlled trial with four arms: i) standard public health recommendation for physical activity; ii) breast cancerspecific physical activity print materials; iii) use of a step pedometer; or iv) a combination of print materials and use of a step pedometer. Physical activity increased by three minutes/week in the standard recommendation group compared with 70 minutes/week in the print material group ( $\mathrm{p}=0.117), 89$ minutes/week in the pedometer group ( $\mathrm{p}=0.017)$, and 87 minutes/week in the combined group $(\mathrm{p}=0.022)$. For brisk walking, all three intervention groups reported significantly greater increases than the standard recommendation group. The combined group also reported significantly improved quality-oflife $(\mathrm{p}=0.003)$ and reduced fatigue $(\mathrm{p}=0.052)$.

In a 12-week randomized controlled trial of a homebased walking intervention, Matthews et al. ${ }^{[13]}$ found that intervention participants reported a significantly greater increase in walking for exercise than the controls $(\mathrm{p}=0.01)$. In a 12-week randomized controlled trial of two home-based exercise programs (aerobic exercise, resistance training), Yuen and Sword ${ }^{[14]}$ found a significant reduction in fatigue among participants in the aerobic exercise group compared with the resistance exercise group $(\mathrm{p}=0.006)$. In addition, there was a significant improvement in the distance walked during a 6-minute walk test in the resistance exercise group $(\mathrm{p}=0.009)$.

Payne et al..$^{[15]}$ conducted a randomized controlled trial of a home-based walking program among 20 women receiving hormonal therapy for breast cancer. There was 
Table 1. Studies of home-based physical activity interventions for breast cancer survivors

\begin{tabular}{|c|c|c|c|c|}
\hline Author & Design & Outcomes & Sample Size & Results \\
\hline Pinto et al., 2005 & $\begin{array}{l}\text { 12-week randomized controlled trial of physical } \\
\text { activity counseling delivered via telephone, } \\
\text { combined with weekly exercise tip sheets }\end{array}$ & $\begin{array}{l}\text { Self-reported minutes of } \\
\text { physical activity }\end{array}$ & $\begin{array}{l}86 \text { women who had completed } \\
\text { therapy for stage } 0 \text {-II breast } \\
\text { cancer }\end{array}$ & $\begin{array}{l}\text { The physical activity group reported significantly more total minutes of } \\
\text { physical activity and more minutes of moderate-intensity physical activity } \\
(\mathrm{p}=0.001)\end{array}$ \\
\hline $\begin{array}{l}\text { Wilson et al., } \\
2005\end{array}$ & $\begin{array}{l}\text { 8-week pre-/ post-test trial of a community } \\
\text { intervention using pedometers with scheduling, } \\
\text { goal setting, and self-assessment }\end{array}$ & $\begin{array}{l}\text { Steps walked per day, body } \\
\text { mass index, and attitudes }\end{array}$ & $\begin{array}{l}24 \text { African American breast } \\
\text { cancer survivors }\end{array}$ & $\begin{array}{l}\text { Significant increases in steps walked per day and attitude toward exercise } \\
\text { were reported, as well as significant decreases in body mass index and other } \\
\text { anthropometric measures }\end{array}$ \\
\hline $\begin{array}{l}\text { Vallance et al., } \\
2007\end{array}$ & $\begin{array}{l}\text { 12-week randomized controlled trial with } 4 \text { arms: } \\
\text { standard public health recommendation for } \\
\text { physical activity; breast cancer-specific physical } \\
\text { activity print materials; a step pedometer; or a } \\
\text { combination of print materials and step } \\
\text { pedometers }\end{array}$ & $\begin{array}{l}\text { Self-reported } \\
\text { moderate/vigorous physical } \\
\text { activity minutes per week. } \\
\text { Secondary outcomes were } \\
\text { quality-of-life, fatigue, self- } \\
\text { reported brisk walking, and } \\
\text { objective step counts }\end{array}$ & $\begin{array}{l}377 \text { women who had } \\
\text { completed therapy for stage I- } \\
\text { IIIa breast cancer }\end{array}$ & $\begin{array}{l}\text { Physical activity increased by } 3 \text { - minutes/week in the standard } \\
\text { recommendation group compared with } 70 \text { minutes/week in the print } \\
\text { material group ( } \mathrm{p}=0.117,89 \text { minutes/week in the pedometer group } \\
(\mathrm{p}=0.017) \text {, and } 87 \text { minutes/week in the combined group ( } \mathrm{p}=0.022) \text {. For } \\
\text { brisk walking, all three intervention groups reported significantly greater } \\
\text { increases than the standard recommendation group. The combined group } \\
\text { also reported significantly improved quality-of-life }(\mathrm{p}=0.003 \text { ) and reduced } \\
\text { fatigue ( } \mathrm{p}=0.052 \text { ). }\end{array}$ \\
\hline $\begin{array}{l}\text { Matthews et al., } \\
2007\end{array}$ & $\begin{array}{l}\text { 12-week randomized controlled trial of a home- } \\
\text { based walking intervention }\end{array}$ & Self-reported physical activity & 36 breast cancer survivors & $\begin{array}{l}\text { Intervention participants reported a significantly greater increase in walking } \\
\text { for exercise }(\mathrm{p}=0.01)\end{array}$ \\
\hline $\begin{array}{l}\text { Yuen \& Sword, } \\
2007\end{array}$ & $\begin{array}{l}\text { 12-week randomized controlled trial of two home- } \\
\text { based exercise programs (aerobic exercise, } \\
\text { resistance training) }\end{array}$ & $\begin{array}{l}\text { Fatigue, functional capacity } \\
\text { (6-minute walk test) }\end{array}$ & & $\begin{array}{l}\text { There was a significant reduction in fatigue among participants in the } \\
\text { aerobic exercise group }(\mathrm{p}=0.006) \text {. There was a significant improvement in } \\
\text { the distance of the } 6 \text {-minute walk test in the resistance exercise group } \\
(\mathrm{p}=0.009)\end{array}$ \\
\hline Payne et al., 2008 & $\begin{array}{l}\text { Randomized control trial of a home-based } \\
\text { walking program }\end{array}$ & $\begin{array}{l}\text { Fatigue, sleep disturbances, } \\
\text { depressive symptoms, and } \\
\text { biomarkers (cortisol, } \\
\text { serotonin, interleukin-6, } \\
\text { bilirubin) }\end{array}$ & $\begin{array}{l}20 \text { women receiving hormonal } \\
\text { therapy for breast cancer }\end{array}$ & $\begin{array}{l}\text { There was a significant improvement in sleep scores in the intervention } \\
\text { group compared with the control group }(\mathrm{p}=0.007) \text {. Serotonin levels were } \\
\text { also significantly different between groups }(\mathrm{p}=0.009)\end{array}$ \\
\hline Yang et al., 2010 & $\begin{array}{l}\text { 12-week randomized controlled trial of a home- } \\
\text { based walking program }\end{array}$ & $\begin{array}{l}\text { Symptom severity score and } \\
\text { mood disturbance }\end{array}$ & $\begin{array}{l}40 \text { breast cancer patients } \\
\text { (stage I-IIIa) receiving an } \\
\text { aromatase inhibitor }\end{array}$ & $\begin{array}{l}\text { Women in the exercise group reported significantly lower symptom severity } \\
\text { scores ( }<0.01) \text { and mood disturbance }(\mathrm{p}=0.02) \text { compared with those in the } \\
\text { control group }\end{array}$ \\
\hline Kim et al. 2011 & $\begin{array}{l}\text { 12-week randomized controlled trial of a home- } \\
\text { based stage-matched exercise and diet } \\
\text { intervention (telephone counseling and a } \\
\text { workbook }\end{array}$ & $\begin{array}{l}\text { Stage of motivational } \\
\text { readiness for exercise and } \\
\text { diet, physical activity, diet } \\
\text { quality, quality-of-life, } \\
\text { fatigue, anxiety, depression }\end{array}$ & $\begin{array}{l}45 \text { breast cancer survivors, } \\
\text { stage } 0 \text {-III }\end{array}$ & $\begin{array}{l}\text { The intervention group showed significantly greater improvement in } \\
\text { motivational readiness for exercise }(\mathrm{p}<0.006) \text { and diet }(\mathrm{p}<0.001) \text {, emotional } \\
\text { functioning }(\mathrm{p}=004) \text {, fatigue }(\mathrm{p}=0.001) \text {, and depression }(\mathrm{p}=0.035)\end{array}$ \\
\hline $\begin{array}{l}\text { Hatchett et al., } \\
2013\end{array}$ & $\begin{array}{l}\text { 12-week randomized controlled trial of an email } \\
\text { physical activity intervention }\end{array}$ & Self-reported physical activity & 74 breast cancer survivors & $\begin{array}{l}\text { Significant differences in levels of physical activity were observed between } \\
\text { groups at } 6(p=0.001) \text { and } 12 \text { weeks }(p<0.001)\end{array}$ \\
\hline $\begin{array}{l}\text { Spector et al., } \\
2014\end{array}$ & $\begin{array}{l}\text { Pre-/post-test trial of a home-based aerobic and } \\
\text { resistance training exercise intervention } \\
\text { (motivational interviewing and weekly telephone } \\
\text { calls) }\end{array}$ & $\begin{array}{l}\text { Self-reported and objectively } \\
\text { assessed physical activity, } \\
\text { quality-of-life, and fatigue }\end{array}$ & $\begin{array}{l}17 \text { African American women } \\
\text { who had completed therapy } \\
\text { for stage } 0 \text {-IIIa breast cancer, } \\
\text { who were currently sedentary }\end{array}$ & $\begin{array}{l}\text { There was a significant increase in total minutes of weekly physical activity } \\
(\mathrm{p}=0.001) \text {. Total quality-of-life and fatigue scores improved, but neither } \\
\text { was significant. }\end{array}$ \\
\hline $\begin{array}{l}\text { Denysschen et al., } \\
2014\end{array}$ & $\begin{array}{l}\text { 8-week pre-/ post-test trial of a home-based } \\
\text { exercise program (resistance exercises and self- } \\
\text { selected aerobic exercise) }\end{array}$ & $\begin{array}{l}\text { Anthropometry and functional } \\
\text { performance and } \\
\text { cardiovascular endurance (3- } \\
\text { minute step test) }\end{array}$ & $\begin{array}{l}26 \text { breast cancer patients } \\
\text { receiving an aromatase } \\
\text { inhibitor }\end{array}$ & $\begin{array}{l}\text { Participants reported a significantly lower number of painful joints, and } \\
\text { improved quality-of-life }(\mathrm{p}<0.05) \text {. Significant improvements in grip } \\
\text { strength ( }<0.01) \text {, biceps curl }(\mathrm{p}<0.01) \text {, and sit-to-stand were also observed. } \\
\text { There were no significant differences in anthropometric measures or } \\
\text { cardiovascular endurance. }\end{array}$ \\
\hline $\begin{array}{l}\text { Baruth et al., } \\
2015\end{array}$ & $\begin{array}{l}\text { 12-week randomized controlled trial of a home- } \\
\text { based walking program }\end{array}$ & $\begin{array}{l}\text { Self-reported fatigue, quality- } \\
\text { of-life, and walking }\end{array}$ & $\begin{array}{l}32 \text { women who were early } \\
\text { stage breast cancer survivors }\end{array}$ & $\begin{array}{l}\text { Participants in the intervention group had improvements in fatigue and } \\
\text { quality of life outcomes. Changes in fatigue and quality of life were } \\
\text { associated with changes in walking behavior }\end{array}$ \\
\hline Lahart et al., 2016 & $\begin{array}{l}\text { 6-month randomized controlled trial of a physical } \\
\text { activity intervention (face-to-face and telephone } \\
\text { physical activity counseling) }\end{array}$ & $\begin{array}{l}\text { Physical activity (primary } \\
\text { outcome) and body mass, } \\
\text { body mass index, body fat, } \\
\text { health-related quality-of-life, } \\
\text { insulin resistance, and lipids }\end{array}$ & $\begin{array}{l}80 \text { post-adjuvant therapy } \\
\text { breast cancer patients }\end{array}$ & $\begin{array}{l}\text { Total, leisure and vigorous physical activity significantly increased in the } \\
\text { intervention group compared to usual care group ( } \mathrm{p}=0.24, \mathrm{p}=0.01 \text {, and } \\
\mathrm{p}=0.007 \text {, respectively). Both body mass and body mass index decreased } \\
\text { significantly in the intervention group compared to usual care group } \\
(\mathrm{p}=0.04 \text { and } \mathrm{p}=0.02 \text {, respectively). Total cholesterol and LDL-cholesterol } \\
\text { decreased significantly in the intervention group compared to usual care } \\
\text { group ( } \mathrm{p}=0.001 \text { and } \mathrm{p}=0.23 \text {, respectively). }\end{array}$ \\
\hline Knobf et al., 2016 & $\begin{array}{l}\text { 12-month randomized controlled trial of a } \\
\text { aerobic-resistance exercise intervention compared } \\
\text { to a home-based physical activity intervention }\end{array}$ & $\begin{array}{l}\text { Bone mineral density and } \\
\text { biomarkers of bone turnover }\end{array}$ & $\begin{array}{l}154 \text { early postmenopausal } \\
\text { breast cancer survivors }\end{array}$ & $\begin{array}{l}\text { No significant difference in bone mineral density was observed between the } \\
\text { two groups }\end{array}$ \\
\hline Nyrop et al., 2017 & $\begin{array}{l}\text { 6-week randomized controlled trial of a home- } \\
\text { based walking program }\end{array}$ & $\begin{array}{l}\text { Self-reported joint symptoms } \\
\text { and psychosocial measures }\end{array}$ & $\begin{array}{l}62 \text { post-menopausal women } \\
\text { diagnosed with stage } 0 \text {-III } \\
\text { breast cancer, with aromatase } \\
\text { inhibitor-associated arthralgia }\end{array}$ & $\begin{array}{l}\text { Intervention group participants reported significantly increased walking } \\
\text { minutes per week, reduced stiffness, less difficulty with activities of daily } \\
\text { living, and less perceived helplessness in managing joint symptoms }\end{array}$ \\
\hline Valle et al., 2017 & $\begin{array}{l}\text { 3-arm, 6-month randomized controlled trial of a } \\
\text { physical activity intervention (activity tracker and } \\
\text { tailored feedback based on objective weight; } \\
\text { tailored feedback alone; or control) }\end{array}$ & Change in weight & $\begin{array}{l}35 \text { African American breast } \\
\text { cancer survivors, stage I-IIIa }\end{array}$ & $\begin{array}{l}\text { Median weight change was }-0.9 \text { in the intervention group that included } \\
\text { activity trackers vs. } 0.2 \% \text { gain in the control group }\end{array}$ \\
\hline $\begin{array}{l}\text { Westphal et al., } \\
2018\end{array}$ & $\begin{array}{l}\text { 48-week multi-center randomized controlled trial } \\
\text { of counseling and unsupervised exercise training } \\
\text { vs. supervised physical training ( } 24 \text { weeks) } \\
\text { followed by unsupervised training (additional } 24 \\
\text { weeks). The supervised training was comprised } \\
\text { of } 45 \text { minutes of stationary cycling and } 30 \\
\text { minutes of resistance training twice a week. }\end{array}$ & $\begin{array}{l}\text { Maximum power output on a } \\
\text { cycle ergometer after } 24 \\
\text { weeks of exercise }\end{array}$ & $\begin{array}{l}42 \text { early-stage breast cancer } \\
\text { patients receiving aromatase } \\
\text { inhibitor treatment }\end{array}$ & $\begin{array}{l}\text { After } 24 \text { weeks, the supervised arm achieved a significantly higher } \\
\text { maximum output in watt (mean } 132+/ \text { - SD } 34,95 \% \text { CI } 117-147) \text { compared } \\
\text { to baseline } 107+/-25,95 \% \text { CI } 97-117, \mathrm{p}=0.012) \text { with a higher output than } \\
\text { the unsupervised arm }(115+/-25,95 \% \text { CI } 105-125, P=0.059) \text {. }\end{array}$ \\
\hline $\begin{array}{l}\text { Hirschey et al., } \\
2018\end{array}$ & $\begin{array}{l}\text { Randomized controlled trial of a home-based } \\
\text { physical activity intervention (a booklet about } \\
\text { physical activity for breast cancer survivors, that } \\
\text { included narrative messages and writing and } \\
\text { thinking exercises) }\end{array}$ & $\begin{array}{l}\text { Multidimensional exercise } \\
\text { outcome measure }\end{array}$ & $\begin{array}{l}60 \text { breast cancer survivors, } \\
\text { stage Ia-IIb }\end{array}$ & $\begin{array}{l}\text { Subjective exercise (weekly minutes) increased } 2 \text { minutes, and objective } \\
\text { exercise increased by } 970 \text { steps, every } 4 \text { weeks in the intervention group } \\
\text { compared to the control group ( } \mathrm{p}=0.2676 \text { and } \mathrm{p}=0.0283 \text {, respectively) }\end{array}$ \\
\hline Bail et al., 2018 & $\begin{array}{l}\text { 12-month randomized controlled trial of a home- } \\
\text { based mentored vegetable gardening intervention }\end{array}$ & $\begin{array}{l}\text { Vegetable consumption, } \\
\text { physical activity, performance } \\
\text { and function, } \\
\text { anthropometrics, biomarkers, } \\
\text { quality-of-life }\end{array}$ & $\begin{array}{l}82 \text { breast cancer survivors, } \\
\text { stage } 0 \text {-III }\end{array}$ & $\begin{array}{l}\text { Compared with the controls, intervention participants reported significantly } \\
\text { greater improvements in moderate physical activity and demonstrated } \\
\text { improvements in the 2-minute step test and arm curl (p-values }<0.05 \text { ). }\end{array}$ \\
\hline Lahart et al., 2018 & $\begin{array}{l}\text { 6-month randomized controlled trial of a home- } \\
\text { based physical activity intervention }\end{array}$ & $\begin{array}{l}\text { Cardiorespiratory fitness and } \\
\text { physical activity }\end{array}$ & $\begin{array}{l}32 \text { breast cancer survivors } \\
\text { who had completed adjuvant } \\
\text { therapy }\end{array}$ & $\begin{array}{l}\text { Magnitude-based inference analyses revealed at least small beneficial effects } \\
\text { on absolute and relative } V \mathrm{O}_{2} \text { max (cardiorespiratory fitness), and total and } \\
\text { moderate physical activity in the intervention compared to the usual care } \\
\text { group. }\end{array}$ \\
\hline
\end{tabular}

Current Cancer Reports (C) 2019 by Syncsci Publishing. All rights reserved. 
a significant improvement in sleep scores in the intervention group compared with the control group $(\mathrm{p}=$ 0.007). Serotonin levels were also significantly different between groups $(\mathrm{p}=0.009)$.

Yang et al. ${ }^{[16]}$ conducted a 12-week randomized controlled trial of a home-based walking program among 40 breast cancer patients who were receiving an aromatase inhibitor. Women in the exercise group reported significantly lower symptom severity scores $(p<0.01)$ and mood disturbance $(\mathrm{p}=0.02)$ compared with those in the control group.

In a 12-week randomized controlled trial of a homebased, stage-matched, exercise and diet intervention (telephone counseling and a workbook), Kim et al. ${ }^{[17]}$ found that the intervention group showed significantly greater improvement in emotional functioning $(\mathrm{p}=0.04)$, and motivational readiness for exercise $(\mathrm{p}<0.006)$ and dieting $(\mathrm{p}<0.001)$, and reduced fatigue $(\mathrm{p}=0.001)$ and depression $(p=0.035)$ than the controls.

In a 12-week randomized controlled trial of an email physical activity intervention, Hatchett et al. ${ }^{[18]}$ observed significantly higher levels of physical activity in the intervention group at six $(\mathrm{p}=0.001)$ and 12 weeks $(\mathrm{p}<0.001)$ compared to the controls.

Spector et al. ${ }^{[19]}$ conducted a pre/post-test trial of a home-based aerobic and resistance training exercise intervention. The intervention included motivational interviewing and weekly telephone calls. They found a significant increase in total minutes of weekly physical activity $(p=0.001)$. Total quality-of-life and fatigue scores improved, but neither improvement was statistically significant.

Denysschen et al. ${ }^{[20]}$ conducted an eight-week pre/post-test trial of a home-based exercise program (resistance exercises and self-selected aerobic exercise) among 26 breast cancer patients who were receiving an aromatase inhibitor. The participants reported a significantly lower number of painful joints and significantly improved quality-of-life $(\mathrm{p}<0.05)$. Significant improvements in grip strength $(\mathrm{p}<0.01)$, biceps curl $(\mathrm{p}<0.01)$, and sit-to-stand were also observed. There were no significant differences in anthropometric measures or cardiovascular endurance.

In a 12-week randomized controlled trial of a homebased walking program among 32 early-stage breast cancer survivors, Baruth et al.$^{[21]}$ found that participants in the intervention group had reduced fatigue and improvement in other quality of life outcomes.

Lahart et al. ${ }^{[22]}$ conducted a six-month randomized controlled trial of a physical activity intervention (face-to-face and telephone physical activity counseling) among 80 breast cancer survivors. Total, leisure, and vigorous physical activity increased in the intervention group compared to the usual care group $(\mathrm{p}=0.24, \mathrm{p}=$ 0.01 , and $\mathrm{p}=0.007$, respectively). Both body mass and body mass index decreased significantly in the intervention group compared to the usual care group $(p=0.04$ and $p=0.02$, respectively). In addition, total cholesterol and LDL-cholesterol decreased significantly in the intervention group $(\mathrm{p}=0.001)$ but not in the usual care group $(\mathrm{p}=0.23)$.

Knobf et al. ${ }^{[23]}$ conducted a 12-month randomized controlled trial of an aerobic-resistance exercise intervention compared to a home-based physical activity intervention among 154 early postmenopausal breast cancer survivors. The outcomes of interest were bone mineral density and biomarkers of bone turnover. No significant difference in bone mineral density was observed between the two groups.

Nyrop et al. ${ }^{[24]}$ conducted a six-week randomized controlled trial of a home-based walking program among 62 post-menopausal breast cancer patients with aromatase inhibitor-associated arthralgia. Intervention group participants reported significantly increased walking minutes per week, reduced stiffness, less difficulty with activities of daily living, and less perceived helplessness in managing joint symptoms compared to the controls.

Valle et al $^{[25]}$ conducted a two-arm, six-month randomized controlled trial of a physical activity intervention (activity tracker and tailored feedback based on objective weight; tailored feedback alone; or control). The outcome of interest was change in weight. Thirty-five African American breast cancer survivors participated in the trial. Median weight change was $-0.9 \%$ in the intervention group that included activity trackers vs. $0.2 \%$ gain in the control group.

Westphal et al. ${ }^{[26]}$ conducted a 48-week, multi-center, randomized controlled trial of counseling and unsupervised exercise training vs. supervised physical training (24 weeks) followed by unsupervised training (additional 24 weeks). The supervised training was comprised of 45 minutes of stationary cycling and 30 minutes of resistance training twice a week. After 24 weeks, the supervised arm achieved a significantly higher maximum output in watt (132 $\pm 34,95 \%$ CI: 117-147) compared to baseline $107 \pm 25,95 \% \mathrm{CI}: 97-117, \mathrm{p}=0.012$ ). In addition, output was higher in the supervised arm (115 $\pm 25,95 \%$ CI: $105-125, p=0.059)$ than in the unsupervised arm.

Hirschey et al. ${ }^{[27]}$ conducted a randomized controlled trial of a home-based physical activity intervention (a booklet about physical activity for breast cancer survivors, that included narrative messages and writing and 
thinking exercises) among 60 breast cancer survivors. Subjective exercise (weekly minutes) increased by two minutes, and objective exercise increased by 970 steps every four weeks in the intervention group compared to the control group ( $\mathrm{p}=0.2676$ and $\mathrm{p}=0.0283$, respectively).

Bail et al. ${ }^{[28]}$ conducted a 12-month randomized controlled trial of a home-based mentored vegetable gardening intervention among 82 breast cancer survivors. Compared with the controls, intervention participants reported significantly greater improvements in moderate physical activity and demonstrated improvements in the two-minute step test and arm curl $(\mathrm{p}<0.05)$.

Lahart et al. ${ }^{[29]}$ conducted a six-month randomized controlled trial of a home-based physical activity intervention involving 32 breast cancer survivors. Magnitude-based inference analyses revealed at least small beneficial effects on absolute and relative $\mathrm{VO}_{2}$ max (cardiorespiratory fitness), and total and moderate physical activity in the intervention compared to the usual care group.

\section{Discussion}

The results of this systematic literature review indicate that home-based exercise programs are effective in improving physical activity among breast cancer survivors who have completed primary therapy for the disease. A variety of outcomes were assessed in the trials, including self-reported minutes of physical activity, steps walked per day, functional capacity, cardiovascular endurance, body mass index, weight, sleep scores, quality-of-life, and attitudes toward physical activity. In the one trial that assessed bone mineral density as an outcome ${ }^{[6]}$, no significant difference was observed between the two groups. A variety of intervention strategies have been tested in trials of home-based exercise programs, including aerobic and resistance exercise training, walking programs, print materials, telephone counseling, and gardening. A majority of the outcomes measured in the trials using one or more of the intervention strategies demonstrated positive change in the intervention groups compared to the controls. These studies yielded encouraging information and reflected the acceptance of innovative methods of physical activity interventions by breast cancer survivors.

Three studies of the effectiveness of home-based exercise programs focused on African American breast cancer survivors ${ }^{[11,19,25]}$. The results of these studies indicated that home-based exercise programs are effective in increasing physical activity and reducing weight among African American breast cancer survivors.
Four studies of the effectiveness of home-based exercise programs focused on women receiving aromatase inhibitor therapy for breast cancer ${ }^{[20,24,26]}$. The results of these studies indicated that home-based exercise programs are effective in reducing joint pain and increasing mobility among women receiving this therapy.

Two RCTs focused on using an email physical activity intervention among breast cancer survivors ${ }^{[17,18]}$. Both studies were effective using email, showing improvement with motivation readiness for exercise, diet, emotional functioning, depression and significant differences in physical activity.

Four studies on the effectiveness of home-based walking interventions focused on breast cancer survivors, with one of the groups in each study receiving hormonal therapy ${ }^{[13-15,21]}$. These studies demonstrated that homebased walking interventions are effective in increasing walking for exercise, reducing fatigue, and improving quality of life. Those receiving hormonal therapy reported improvement in sleep scores and increased serotonin levels.

With respect to limitations, outcomes, intervention strategies, and tests varied among the studies. Caution is therefore required in comparing results across studies. In addition, our literature review may not have captured all relevant studies.

In summary, home-based exercise programs are effective in improving physical activity among breast cancer survivors who have completed primary therapy for the disease. This includes women who are receiving aromatase inhibitor therapy for breast cancer. Home-based exercise programs, such as walking programs offer a convenient and affordable option for women who wish to increase their physical activity and maintain a healthy lifestyle.

\section{Conflict of interest}

The authors declare they have no conflicts of interest.

\section{Ethical approval}

This article does not contain any studies with human participants performed by any of the authors.

\section{References}

[1] American Cancer Society. Cancer Facts \& Figures 2019. Atlanta: American Cancer Society, 2019.

[2] Zhang X, Li Y and Liu D. Effects of exercise on the quality of life in breast cancer patients: a systematic review of randomized controlled trials. Supportive Care in Cancer, 2019, 27(1): 9-21. https://doi.org/10.1007/s00520-018-4363-2 
[3] World Cancer Research Fund Report "Food, Nutrition, Physical Activity, and the Prevention of Cancer: a Global Perspective". 2007, 1(10): 464-469. https://doi.org/10.1007/s12082-007-0105-4

[4] Vance V, Mourtzakis M, McCargar L, et al. Weight gain in breast cancer survivors: prevalence, pattern and health consequences. Obesity Reviews, 2011, 12(4): 282-94. https://doi.org/10.1111/j.1467-789X.2010.00805.x

[5] Rock CL and Demark-Wahnefried W. Nutrition and Survival after the Diagnosis of Breast Cancer: A Review of the Evidence. Journal of Clinical Oncology, 2002, 20(15): 3302-3316. https://doi.org/10.1200/JCO.2002.03.008

[6] Knobf MT, Thompson SA, Fennie K, et al. The Effect of a Community-Based Exercise Intervention on Symptoms and Quality of Life. Cancer Nursing, 2014, 37(2): E43-E50. https://doi.org/10.1097/NCC.0b013e318288d40e

[7] Smith SA, Ansa BE, Yoo W, et al. Determinants of adherence to physical activity guidelines among overweight and obese African American breast cancer survivors: impliations for an intervention approach. Ethnicity \& Health, 2018, 23(2): 194-206. https://doi.org/10.1080/13557858.2016.1256376

[8] Coughlin SS and Smith SA. The insulin-like growth factor axis adipokines, physical activity, and obesity in relation to breast cancer incidence and recurrence. Cancer and Clinical Oncology, 2015, 4(2): 24-31. https://doi.org/10.5539/cco.v4n2p24

[9] Schmidt T, van Mackelenbergh M, Wesche D, et al. Physical activity influences the immune system of breast cancer patients. Journal of Cancer Research and Therapeutics, 2017, 13(3): 392-398. https://doi.org/10.4103/0973-1482.150356

[10] Pinto BM, Frierson M, Rabin C, et al. Home-based physical activity intervention for breast cancer patients. Journal of Clinical Oncology, 2005, 23(15): 3577-3587. https://doi.org/10.1200/JCO.2005.03.080

[11] Wilson DB, Porter JS, Parker G, et al. Anthropometric changes using a walking intervention in African American breast cancer survivors: a pilot study. Preventing Chronic Disease, 2005, 2(2): 1-7. https://www.cdc.gov/pcd/issues/2005/apr/04_0112.htm

[12] Vallance KH, Courneya KS, Plotnikoff RC, et al. Randomized controlled trial of the effects of print materials and step pedometers on physical activity and quality of life in breast cancer survivors. Journal of Clinical Oncology, 2007, 25(17): 2352-2359. https://doi.org/10.1200/JCO.2006.07.9988

[13] Matthews CE, Wilcox S, Hanby CL, et al. Evaluation of a 12-week home-based walking intervention for breast cancer survivors. Supportive Care in Cancer, 2007, 15(2): 203-211. https://doi.org/10.1007/s00520-006-0122-x

[14] Yuen HK and Sword D. Home-based exercise to alleviate fatigue and improve functional capacity among breast cancer survivors. Journal of allied health, 2007, 36(4): e257-275.

[15] Payne JK, Held J, Thorpe J, et al. Effect of exercise on biomarkers, fatigue, sleep disturbances, and depressive symptoms in older women with breast cancer receiving hormonal therapy. Oncology Nursing Forum, 2008, 35(4): 635642.

https://doi.org/10.1188/08.ONF.635-642
[16] Yang CY, Tsai JC, Huang YC, et al. Effects of a home-based walking program on perceived symptom and mood status in post-operative breast cancer women receiving adjuvant chemotherapy. Journal of Advanced Nursing, 2011, 67(1): 158-168.

https://doi.org/10.1111/j.1365-2648.2010.05492.x

[17] Kim SH, Shin MS, Lee HS, et al. Randomized pilot test of a simultaneous stage-matched exercise and diet intervention for breast cancer survivors. Oncology Nursing Forum, 2011, 38(2): E97-E106.

https://doi.org/10.1188/11.ONF.E97-E106

[18] Hatchett A, Hallam JS and Ford MA. Evaluation of a social cognitive theory-based email intervention designed to influence the physical activity of survivors of breast cancer. Psycho-Oncology, 2013, 22(4): 829-836. https://doi.org/10.1002/pon.3082

[19] Spector D, Deal AM, Amos KD, et al. A pilot study of a home-based motivational exercise program for African American breast cancer survivors: clinical and quality-oflife outcomes. Integrative Cancer Therapies, 2014, 13(2): 121-132. https://doi.org/10.1177/1534735413503546

[20] Denysschen CA, Burton H, Ademuyiwa F, et al. Exercise intervention in breast cancer patients with aromatase inhibitor-associated arthralgia: a pilot study. European Journal of Cancer Care, 2014, 23(4): 493-501. https://doi.org/10.1111/ecc.12155

[21] Baruth M, Wilcox S, Der Ananian C, et al. Effects of home-based walking on quality of life and fatigue outcomes in early stage breast cancer survivors a 12-week pilot study. Journal of Physical Activity and Health, 2015, 12(s1): S110-S118 https://doi.org/10.1123/jpah.2012-0339

[22] Lahart IM, Metsios GS, Nevill AM, et al. Randomized controlled trial of a home-based physical activity intervention in breast cancer survivors. BMC Cancer, 2016, 16: 234. https://doi.org/10.1186/s12885-016-2258-5

[23] Knobf MT, Jeon S, Smith B, et al. Effect of a randomized controlled exercise trial on bone outcomes: influence of adjuvant endocrine therapy. Breast Cancer Research and Treatment, 2016, 155(3): 491-500. https://doi.org/10.1007/s10549-016-3693-3

[24] Nyrop KA, Callahan LF, Cleveland RJ, et al. Randomized controlled trial of a home-based walking program to reduce moderate to severe aromatase inhibitor-associated arthralgia in breast cancer survivors. The Oncologist, 2017, 22(10): 1238-1248. https://doi.org/10.1634/theoncologist.2017-0174

[25] Valle CG, Deal AM and Tate DF. Preventing weight gain in African American breast cancer survivors using smart scales and activity trackers: a randomized controlled pilot study. Journal of Cancer Survivorship, 2017, 11(1): 133-148. https://doi.org/10.1007/s11764-016-0571-2

[26] Westphal T, Rinnerthaler G, Gampenrieder SP, et al. Supervised versus autonomous exercise training in breast cancer patients: a multicenter randomized clinical trial. Cancer Medicine, 2018, 7(12): 5962-5972. https://doi.org/10.1002/cam4.1851 
[27] Hirschey R, Kimmick G, Hockenberry M, et al. A randomized phase II trial of MOVING ON: An intervention to increase exercise outcome expectations among breast cancer survivors. Psycho-Oncology, 2018, 27(10): 2450-2457. https://doi.org/10.1002/pon.4849

[28] Bail JR, Fruge AD, Cases MG, et al. A home-based mentored vegetable gardening intervention demonstrates feasibility and improvements in physical activity and performance among breast cancer survivors. Cancer, 2018, 124(16): 3427-3435. https://doi.org/10.1002/cncr.31559

[29] Lahart IM, Carmichael AR, Nevill AM, et al. The effects of a home-based physical activity intervention on cardiorespiratory fitness in breast cancer survivors; a randomised controlled trial. Journal of Sports Sciences, 2018, 36(10): 10771086.

https://doi.org/10.1080/02640414.2017.1356025

( Edited by Snowy Wang ) 